\title{
Japan rolls out elite science funds
}

\section{FIRST scheme targets large grants to world-leading researchers.}

Physicist Akira Tonomura struggled for seven years to raise funding for his dream project: developing a microscope able to image threedimensional arrays of atoms in unprecedented detail. Last March, with little hope of finding this financial support, he even considered retiring from his research fellowship at the Hitachi Advanced Research Laboratory in Hatoyama, Japan.

Then, last month, the Japanese government awarded him $¥ 5$ billion (US\$53.6 million) - the biggest grant for an individual research project in the country's history. Tonomura has already set to work on creating his ultra-high-voltage holographic electron microscope, which will measure the phase of electrons scattering off a sample, rather than their intensity, as in conventional electron microscopes. These phase measurements can produce an image with much higher resolution.

Tonomura was one of 30 scientists to win a grant from the $¥ 100$-billion Funding Program for World-Leading Innovative R\&D on Science and Technology (FIRST). The awards, announced on 9 March after a rollercoaster six months that saw the programme cut drastically, mark a major shift in the landscape of Japanese science funding.

At between $¥ 1.8$ billion and 5 bil-

lion per project, many of the grants are more than double the size of the largest from the Japan Science and Technology Agency, which until now offered the country's most prestigious and generous funding awards. And unlike conventional grants in Japan, FIRST awards give researchers the freedom to spend their grant money at any time during the grant's four-year period.

\section{Funding shift}

In general, FIRST's 30 grants are targeted towards areas in which Japan is already a world leader, such as microscopy, stem-cell research and electronics. Tonomura, one of only two scientists to receive the largest possible FIRST grant of $¥ 5$ billion, pioneered electron holography in the 1960s. The other big winnner

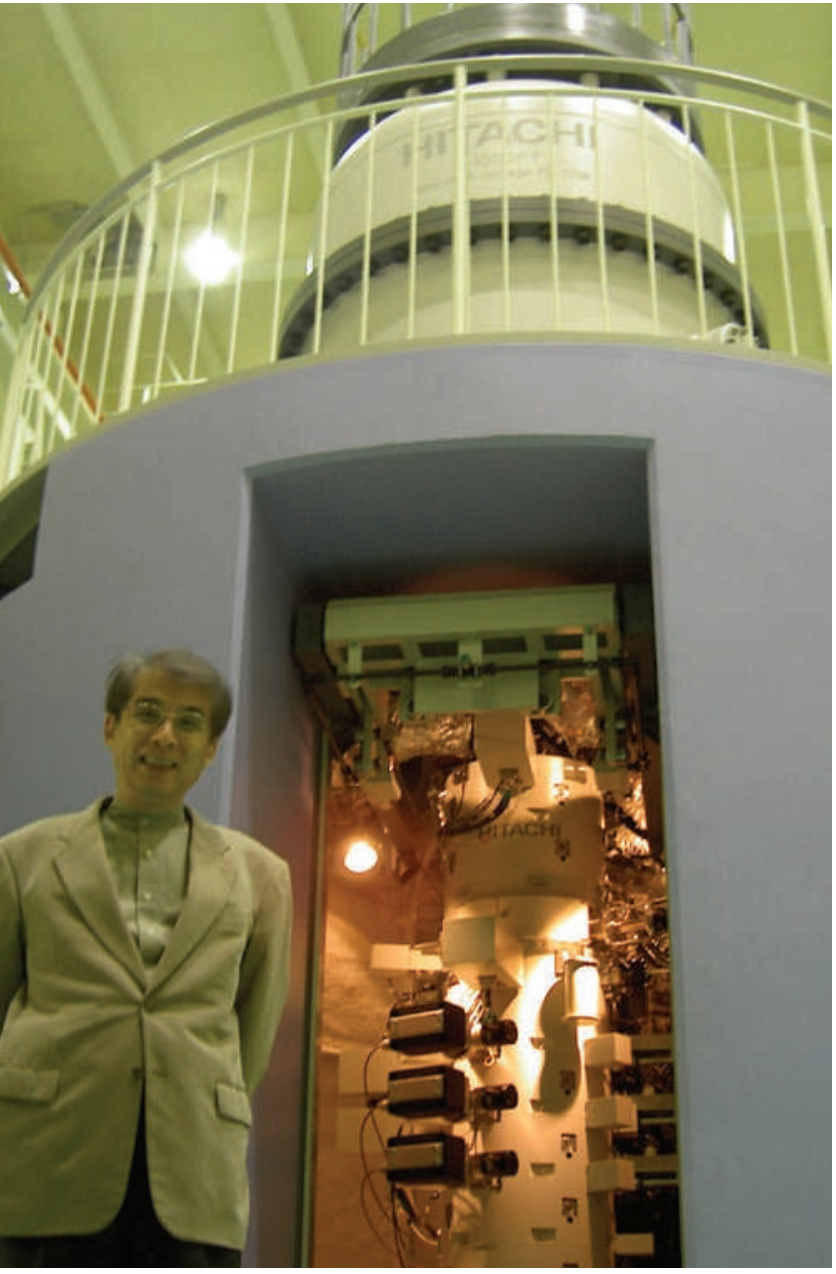

believe could be better spent on a larger number of smaller, focused research projects.

Part of the motivation for the shift in funding was the perception that other countries were benefiting from greater investment in competitive grants. Earlier efforts to direct funding into large competitive grants included a centres of excellence programme rolled out in 2002 (see Nature 419, 547; 2002) and the World Premier International Research Centers that were created in 2007 (see Nature 447, 362-363; 2007).

At the same time, organizational reforms in 2004 saw basic operating budgets for universities and research institutes pared down by $1 \%$ per year. At the University of Tokyo, for example, these operating budgets accounted for $46 \%$ of total income in 2004; this shrank to $40 \%$ by 2009 . However, that decrease was balanced by a growth in competitive funding over the same period, upping its contribution to the university's income from $30 \%$ to $35 \%$. That proportion is sure to grow: the university has won funding for five FIRST projects, bringing in an extra $¥ 17.6$ billion.

Scientists at the university are wasting no time. Although his FIRST funding cheque had yet to arrive, Yoshinori Tokura held a

is Kyoto University's Shinya Yamanaka, who wowed the world of stem-cell research in 2006 with his group's creation of induced pluripotent stem cells.

The awards also mark the latest chapter in Japan's effort to spend a greater proportion of its overall research budget on competitive grants (see 'Getting competitive'), a process that seems to be putting bigger chunks of money into the hands of fewer scientists. It is not yet clear how this shift is affecting the scientific community, says Atsushi Sunami, a science-policy expert at the National Graduate Institute for Policy Studies in Tokyo. However, many scientists in Japan have been privately critical of the heavy concentration of funds, which they
"I want to create a history-making instrument." retreat on 30 March for core members of his $¥ 3.1$-billion study on correlated electrons. The group hopes that controlling the interactions between electrons - based on characteristics such as charge and spin - could help to develop materials useful for energy-efficient electronics, high-temperature superconductors and new types of battery.

Meanwhile, Shizuo Akira of Osaka University has already started spending his ¥2.5-billion FIRST grant, which he says will give him the freedom to "do some gambling" at the frontiers of immunology. Akira - the most cited scientist in the world in 2005-06 and 2006-07, according to academic data-provider Thomson Scientific hopes to create a comprehensive picture of 


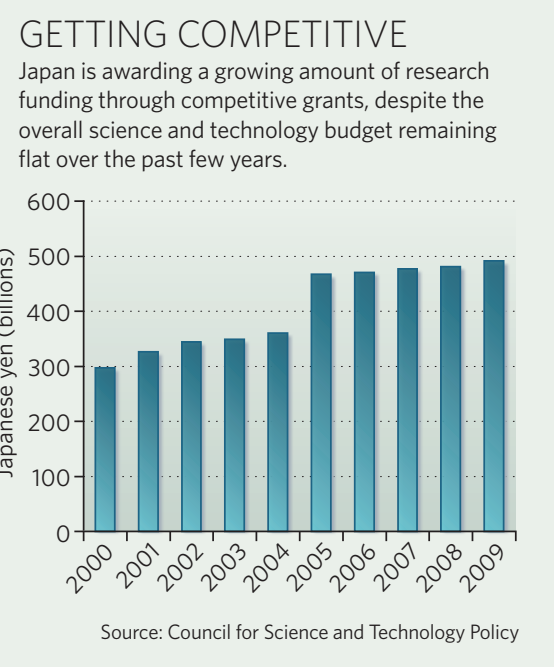

the immunological mechanisms involved in eliminating pathogens and cancer cells, and to then try to control those mechanisms. He has already hired postdocs and technicians, and has ordered a two-photon microscope, an electron microscope, mass-spectrometry equipment and DNA-sequencing machines.

\section{Not so bold}

Despite the air of excitement that the awards have generated, some scientists point out that the FIRST grants were supposed to be bigger, and the projects bolder. In June 2009, the Council for Science and Technology Policy under the then-ruling Liberal Democratic Party announced that FIRST would distribute $¥ 270$ billion. Council members had already selected the 30 recipients before the Democratic Party of Japan came to power.

The new government promised to re-evaluate all large spending programmes (see Nature 461, 854-855; 2009), eventually slashing the budget and capping the largest projects at $¥ 5$ billion. Some scientists had hoped to get considerably more: Yamanaka, for example, originally applied for $¥ 15$ billion.

All of the grantees then had to reapply for their funding with scaled-back projects. "Every strategic research plan was shrunk and every brave enterprise was cut," says Tokura. Yamanaka, for example, has dropped plans to carry out preclinical trials with induced pluripotent stem cells for diabetes and other diseases. Tonomura, meanwhile, says that his FIRST grant will still leave him $¥ 2$ billion short of what his project requires, an amount he hopes to persuade Hitachi to chip in.

But with the money he already has in hand, he has no immediate plans to retire: "I want to create a history-making instrument," he says. David Cyranoski

See Editorial, page 957.

\section{Stem-cell funding in sight}

Two of the most widely used embryonic stem (ES) cell lines could be just weeks away from being eligible for US federal funding. The lines, which were approved under the administration of former president George W. Bush, have spent months in limbo pending the go-ahead from the current administration of President Barack Obama. Researchers' frustrations are boiling over at the amount of time lost because of the delays. "The stem-cell community has really been jerked around," says Julie Baker, an associate professor of genetics at Stanford University, California.

The two key cell lines - known as $\mathrm{H} 9$ and $\mathrm{H} 7$ - that Baker and others are desperate to see approved were derived more than a decade ago and are owned by the WiCell Research Institute in Madison, Wisconsin. According to a stem-cell registry maintained by the University of Massachusetts Medical School in Worcester, H9 has led to 551 publications, and $\mathrm{H} 7$ has been used in 133 reports - an order of magnitude more than any of the other 19 Bush-era lines, with the exception of another heavily used WiCell line called $\mathrm{H} 1$, which was approved for federal funding in January.

Under guidelines announced in July 2009 by the US National Institutes of Health (NIH) in Bethesda, Maryland, ES cell lines must meet extensive informedconsent conditions before research using the cells can be funded. Whereas the NIH has approved $51 \mathrm{ES}$ cell lines for federal funding since December 2009, H1 is the only Bush-era line to win the agency's approval so far.

"The H7 [and] H9 submission is still in draft and has not been submitted to the NIH," says NIH spokesman John Burklow, adding that the agency has contacted all of the Bush-era line holders and offered technical assistance in preparing their submissions. "The NIH does recognize that these lines are important to many NIHfunded researchers now and in the future."

Erik Forsberg, executive director of WiCell, says that he expects approval "in the next month or so" for four outstanding WiCell lines, including $\mathrm{H} 7$ and H9. "We are extraordinarily close to getting all the documents that we anticipate are needed for approval," he says. But scientists are still concerned that there could be further hitches. "With the Obama administration, we thought things were going to get better, and this is almost worse," says Baker. "If they don't approve these lines, we have to go backwards."

It's crucial that the lines held by WiCell are approved, adds Joseph Itskovitz-Eldor, a stem-cell expert at the Technion-Israel Institute of Technology in Haifa, who helped to derive the four $\mathrm{H}$-lines held by WiCell using donated Israeli embryos. "They are being used so widely. To switch to other cell lines is going to be timeconsuming and costly."

Gathering the paperwork needed for the NIH application has been slowed by translation requirements (the original documents are in Hebrew) and other problems. One donating couple had not been informed that the lines could be used commercially and that they would not benefit financially - requirements that are spelled out in the NIH guidelines. ItskovitzEldor e-mailed patient re-consent forms, and institutional review board approvals for them, to WiCell on 8 April. "At this point, we have completed our part. But I am sure that more documents will be needed. The whole process may take some weeks or maybe more," he says.

The hoped-for approval can't come soon enough for Baker, who almost exclusively uses H9 in her lab. "The one that's really easy to produce in the lab, which grows well, is H9. That's why all the publications use it," she says. In early March, Baker submitted an NIH grant application to use $\mathrm{H} 9$ to examine how ES cells use cell signalling to form endoderm, which gives rise to many internal tissues. If $\mathrm{H} 9$ is not approved soon, she plans to write to reviewers and suggest that she switch to using $\mathrm{H} 1$. But that would require extra work to extrapolate data she has already generated in "extremely expensive" H9 experiments to $\mathrm{H} 1$.

Even if the four outstanding WiCell lines are approved, that still leaves 16 Bushera lines unapproved. "Obama made his announcement over a year ago and right now there is only one of the [formerly approved] lines on the federal registry," says Tim Kamp, the director of the Stem Cell and Regenerative Medicine Center at the University of Wisconsin-Madison. "Is it going to take another two months? Another year? We just don't know."

Meredith Wadman 